\title{
Pacientes desnutridos em hemodiálise melhoram após receber intervenção nutricional
}

\author{
Malnourished patients on hemodialysis improve after receiving a \\ nutritional intervention
}

\section{Authors}

Adaiane Calegari ${ }^{1,2}$

Elvino Guardão

Barros $^{2}$

Francisco Veríssimo Veronese ${ }^{2}$

Fernando Saldanha Thomé ${ }^{2}$

${ }^{1}$ Instituto de Doenças

Renais.

${ }^{2}$ Universidade Federal do Rio Grande do Sul UFRGS.

Submitted on: 02/05/2011 Approved on: 16/10/2011

Correspondence to: Fernando SaldanhaThomé Rua Ramiro Barcelos, 2.350 - sala 2030

Porto Alegre - RS - Brazil

Zip code 90035-003

E-mail: daianut@yahoo.

com.br

Financial Support: Instituto de Doenças Renais provided ingredients for the intervention formula.

This study was undertaken at the Nephrology Service of Hospital de Clínicas de Porto Alegre - UFRGS.

The authors report no conflict of interest.

\section{Resumo}

Introdução: A desnutrição é multifatorial e modificável por intervenção nutricional. O objetivo do presente estudo foi avaliar o impacto de uma intervenção sobre o estado nutricional de pacientes desnutridos em hemodiálise e a aceitação deles de um suplemento nutricional não-industrializado. Métodos: 18 pacientes foram estudados, selecionados de uma avaliação nutricional prévia, na qual o risco nutricional foi definido como: avaliação subjetiva global $>15$ mais um critério de desnutrição. As variáveis avaliadas foram: parâmetros antropométricos, avaliação subjetiva global, inquérito alimentar, teste de caminhada de seis minutos, qualidade de vida (SF-36) e exames bioquímicos. Os pacientes foram randomizados para Grupos Controle ou Intervenção. O Grupo Intervenção recebeu suplementação dietética durante a diálise, contendo 355 calorias, preparada com ingredientes simples. Depois de três meses, indivíduos do Grupo Controle e pacientes adicionais considerados em risco nutricional receberam a mesma intervenção. Os Grupos Controle e Intervenção foram comparados após três meses, e os pacientes foram analisados antes e após a intervenção. Resultados: Quinze homens e três mulheres, com idades entre $56,4 \pm 15,6$ anos, nove em cada grupo, foram estudados. O Grupo Intervenção mostrou melhora na avaliação subjetiva global $(p=0,04)$. Houve diferenças nos domínios desempenho físico e dor do SF36, com melhora no Grupo Intervenção e piora no Grupo Controle ( $\mathrm{p}=0,034$ e $p=0,021)$. Comparações entre antes e depois da intervenção nos pacientes mostrou melhora na avaliação subjetiva global $(16,18 \pm 4,27$ versus $14,37 \pm 4,20$, $\mathrm{p}=0,04)$ e no teste de caminhada de seis

\section{Abstract}

Introduction: Malnutrition is multifactorial and may be modified by nutritional intervention. We aimed to assess the impact of an intervention on the nutritional status of malnourished hemodialysis patients and their acceptance of a nonindustrialized nutritional supplement. Methods: 18 patients were studied, they were selected from a previous nutritional assessment where nutritional risk was defined as: subjective global assessment $>15$ plus one criterion for malnutrition. The following variables were assessed: anthropometric parameters, subjective global assessment, dietary intake, six-minute walking test, quality of life (SF-36), and biochemical tests. Patients were randomized to either Control or Intervention Groups. The Intervention Group received a dietetic supplement during dialysis containing $355 \mathrm{kcal}$, prepared from simple ingredients. After three months, subjects from the Control Group and other patients also considered at nutritional risk underwent the same intervention. The study groups were compared after three months, and all patients were analyzed before and after the intervention. Results: Fifteen men and three women, aged $56.4 \pm 15.6$ years-old, nine in each group, were studied. The Intervention Group showed an improvement in the subjective global assessment $(p=0.04)$. There were differences in role physical and bodily pain domains of SF-36, with improvement in the Intervention Group and worsening in the Control Group ( $\mathrm{p}=0.034$ and $p=0.021$ ). Comparisons before and after intervention for all patients showed improvement in the subjective global assessment $(16.18 \pm 4.27$ versus $14.37 \pm 4.20$, 
minutos $(496,60 \pm 132,59$ versus $547,80 \pm 132,48 \mathrm{~m}$; $\mathrm{p}=0,036)$. O suplemento foi bem tolerado pelos pacientes, e não causou para-efeitos. Conclusões: A intervenção nutricional melhorou a avaliação subjetiva global e a qualidade de vida em pacientes em hemodiálise a curto prazo. Uma intervenção global por nutricionista produziu efeitos específicos e não-específicos positivos no grupo. A suplementação nutricional foi factível, palatável e de baixo custo. Seu impacto clínico e sua efetividade precisam ser mais avaliados num grupo maior de pacientes a longo prazo.

Palavras-chave: Desnutrição Proteico-Calórica. Suplementação Alimentar. Avaliação Nutricional. Diálise Renal. Qualidade de Vida. $\mathrm{p}=0.04)$, and in the six-minute walking test $(496.60$ \pm 132.59 versus $547.80 \pm 132.48 \mathrm{~m} ; \mathrm{p}=0.036)$. The nutritional supplement was well tolerated by all patients, and it did not cause side effects. Conclusions: The nutritional intervention improved the subjective global assessment and quality of life of hemodialysis patients at short-term. A global intervention by a dietitian produced specific and nonspecific positive effects in the whole group. Nutritional supplementation was feasible, palatable, and had low cost. Its clinical impact and effectiveness need to be further assessed in a larger group of patients at long-term.

Keywords: Protein-Energy Malnutrition. Nutritional Supplements. Nutrition Assessment. Renal Dialysis. Quality of Life.

\section{INTRODUCTION}

Protein calorie malnutrition (PCM) is a common condition in chronic dialysis (hemodialysis) patients. ${ }^{1}$ Several studies have indicated a prevalence ranging from 18 to $70 \%$ in adult patients. PCM is a strong predictor of morbidity and mortality in this population of patient. ${ }^{2}$

Stenvinkel et al. ${ }^{3}$ have described two types of malnutrition in dialysis patients. Malnutrition type 1 is associated with uremic syndrome or uremia-related factors (physical inactivity, dietary restrictions between dialysis sessions, and psychosocial factors), and low protein-caloric intake. Malnutrition type 2 is associated with a chronic inflammatory response and it is characterized by high levels of C-reactive protein (CRP) and pro-inflammatory cytokines.

Pupim et al. ${ }^{4}$ suggested that oral protein-calorie supplementation is the most affordable, promising, and physiological intervention for HD patients. It is as effective as the intradialytic parenteral nutrition (IDPN) for maintaining a positive net protein balance in the entire body and the in skeletal muscles during $\mathrm{HD}$ in malnourished $(\mathrm{MN})$ patients. It also has lasting benefits in the post-dialysis period.

Veeneman et al..$^{5}$ showed that oral feeding provided during HD acutely improved protein balance. In a prospective study, Caglar et al. ${ }^{6}$ demonstrated that oral nutritional supplementation given to 85 chronic patients on HD was an effective therapy for malnutrition. However, $31 \%$ of these patients did not complete the study.

The purpose of the present study was to assess the impact of a dietetic intervention on the nutritional status of $\mathrm{HD}$ patients at nutritional risk (NR) and their tolerability to a non-industrialized nutritional supplement.

\section{Methods}

\section{Patient Selection}

The study population comprised 78 patients on HD who attended the Divina Providência Hospital, a satellite unit of Hospital de Clínicas of Porto Alegre. Excluded patients were those: clinically unstable; with infectious or inflammatory diseases, neoplasias; scheduled for a transplant; who died or were transferred from the unit before the beginning of the study; and who had been on dialysis for less than three months. Sixty-five patients were included and they underwent a nutritional assessment performed by a dietitian. The assessment consisted of anthropometric measures, laboratory tests, subjective global assessment (SGA), dietary intake, and physical performance.

As several authors have pointed out, the classification of nutritional status requires at least two different methods of assessment. ${ }^{7-10}$ We have chosen to establish criteria to classify patients as $\mathrm{MN}$, i.e., the SGA score higher than nine, and an additional parameter: triceps skinfold (TS) $<90 \%$, arm circumference $(\mathrm{AC})<90 \%$, arm muscle circumference $($ AMC $)<90 \%$, serum albumin $<3.5 \mathrm{~g} / \mathrm{dL}$, or total body mass index $(\mathrm{BMI})<18.5 \mathrm{~kg} / \mathrm{m}^{2}$.

Of the 65 patients, 18 were classified as $\mathrm{MN}$ and they were randomized to the intervention study, which was approved by the Research Ethics Committee of Hospital de Clínicas of Porto Alegre, IRB 00000921. All subjects signed an informed consent. 


\section{STUDY DESIGN}

Subjects were randomized into either a Control Group (C) or an Intervention Group (I). For three months, the Intervention Group received oral intradialytic nutritional supplementation, further described, while the Control Group continued on routine nutritional guidance. This first phase of the study consisted of a comparison between these two groups after three months.

After this period and a one-month washout, the second phase of the study was initiated at which time the Control Group subjects also received the intervention for three months. Three additional patients followed at the HD unit met the criteria for MN and also received the intervention together with the Control Group. Pre- and post- intervention results were analyzed for all patients. Sixteen patients completed the study intervention.

\section{INTERVENTION}

The study intervention consisted of an oral nutritional supplementation during each HD session for a three-month period. This supplementation consisted of: $355 \mathrm{kcal}$ and the following ingredients: $53 \%$ of carbohydrates, $10 \mathrm{~g}$ of proteins, $15 \mathrm{~g}$ of lipids, 257 $\mathrm{mg}$ of calcium, $271 \mathrm{mg}$ of phosphorus, $313 \mathrm{mg}$ of potassium, and $106 \mathrm{mg}$ of sodium. This formula included milk, eggs, crystallized sugar, condensed milk, cornstarch, fruit jelly, and sunflower oil. Instructions for its preparation were as follows: mix the egg yolk with the milk, condensed milk, oil, undissolved jelly, and cornstarch. Cook it until it has the consistency of a cream. Then, add the egg whites and crystallized sugar to the cream and beat until it is thick. Mix and then refrigerate it. Preparation time was 15 minutes. This food supplementation was offered to subjects in the period between the beginning and mid-dialysis. In addition, they were provided with special attention, such as nutritional guidance, family counseling, and dental assessment.

\section{NUTRITIONAL AND QUALITY OF LIFE ASSESSMENTS}

The anthropometric and body composition assessments were carried out with the patient at dry weight by one dietitian after the HD session, using the opposite arm of the arteriovenous fistula. The following anthropometric measures were evaluated: body weight, height, AC, and triceps, biceps, subscapular and suprailiac skinfolds. Lean body mass was measured based on the mid-arm circumference (AMC): $\operatorname{AMC}(\mathrm{cm})=\mathrm{AC}(\mathrm{cm})-(\mathrm{TS})$ in $\mathrm{mm} \times 0.314)$. Lean and fat mass were estimated using Programa de Apoio à Nutrição (NutWin software, Escola Paulista de Medicina, São Paulo, Brazil).

The Kalantar-Zadeh questionnaire $(1999)^{11}$ was applied for the SGA focusing on: weight loss in the last six months; food intake compared to baseline; gastrointestinal symptoms; assessment of functional performance, comorbidities, fat and muscle mass loss, and edema. The final score classifies patients as having adequate nutrition $(\leq 8)$; NR or mild malnutrition (9 to 23 ); and moderate malnutrition (24 to 31 ).

Food intake was assessed using a 24-hour food recall and the NutWin software.

A six-month median of monthly biochemical profiles was calculated for albumin, creatinine, urea, potassium, calcium, phosphorus, total proteins, and serum lymphocytes, and Kt/V was estimated using Daugirdas II formula. ${ }^{12}$ In addition, blood was drawn before and after the nutritional intervention on the day of food recall to measure inflammatory markers, ultra-sensitive $\mathrm{CRP}$, and albumin. Kt/V and protein nitrogen appearance (PNA) were also measured on the same day.

The six-minute walking test (six-min WT) measures the maximum distance a patient can cover walking in a 20 -meter $(\mathrm{m})$ hallway over six minutes. ${ }^{13,14}$

For the assessment of quality of life, the SF-36 questionnaire (The Medical Outcomes Study: 36-Item Short Form Health Survey), translated to Portuguese and validated by Ciconelli, ${ }^{15}$ was used to measure patients' health status. The MOS SF-36 is a multidimensional questionnaire with 36 items comprising eight subscales or domains: physical functioning (PF), social functioning (SF), role physical (RP), role emotional (RE), mental health (ME), vitality (VT), bodily pain (BP), and general health (GH). The answers to each question, in each subscale, were added and converted into eight scores ranging between 0 and 100 . Higher scores indicated better health status. This assessment was self-administered, except in five cases where it was administered by the investigator. Three subjects did not undergo this assessment as they were not able to understand it.

For assessing tolerability to the oral nutritional supplementation, a questionnaire about taste, flavor, palatability, content, appetite, gastrointestinal discomfort, patient's feelings towards an unknown formula, and expectations about the results was applied.

\section{STATISTICAL ANALYSIS}

Statistical analysis was performed using SPSS program, version 16.O (SPSS Inc, Chicago, IL). 
Categorical variables were described as absolute and percent relative frequencies. Quantitative variables were described as mean \pm standard deviation, or median and interquartile range. For the comparison of the Intervention and Control Groups over time, the

\begin{tabular}{|c|c|c|}
\hline Table 1 & \multicolumn{2}{|c|}{$\begin{array}{l}\text { DEMOGRAPHIC AND CLINICAL } \\
\text { CHARACTERISTICS OF HEMODIALYSIS } \\
\text { PATIENTS }\end{array}$} \\
\hline Variables & & Characteristics \\
\hline Gender (M/F & & $15(83.3 \%) / 3(16.7 \%)$ \\
\hline Age (years) & & $\begin{array}{l}56.4 \pm 15.58 \\
\text { (range: } 26 \text { to } 88 \text { years) }\end{array}$ \\
\hline \multicolumn{3}{|l|}{ CKD etiology } \\
\hline \multicolumn{2}{|c|}{ Arterial hypertension } & $6(33.3 \%)$ \\
\hline \multicolumn{2}{|c|}{ Diabetes mellitus } & $5(27.8 \%)$ \\
\hline \multicolumn{2}{|c|}{ Polycystic kidneys } & $1(5.6 \%)$ \\
\hline \multicolumn{2}{|c|}{ Other or unknown } & $6(33.3 \%)$ \\
\hline \multicolumn{2}{|c|}{ Duration of dialysis (months) } & $\begin{array}{c}81.6 \pm 36.76 \\
\text { (range: } 18 \text { to } 353 \text { months) }\end{array}$ \\
\hline
\end{tabular}

$\mathrm{n}=18 ;$ CKD: chronic kidney disease. analysis of variance (ANOVA) was used for repetitive measures. Differences between clinical data pre- and post- supplementation were assessed by Student's $t$ test for paired samples and Wilcoxon's test using a significance level of $5 \%(\mathrm{p} \leq 0.05)$.

\section{Results}

Demographic data and clinical characteristics of 18 subjects are presented in Table 1 .

Of the 18 subjects at MN, $12(66.6 \%)$ had major comorbidities, $11(61 \%)$ had MN type 1 and 7 $(39 \%)$ had $\mathrm{MN}$ type 2 with CRP > $5 \mathrm{mg} / \mathrm{L}$. Total lymphocyte count $\left(<1,500 \mathrm{~mm}^{3}\right)$ was low in 9 out of 18 subjects at MN. Fifteen subjects completed the first phase of the study. Two subjects died and one moved to peritoneal dialysis (PD), all from the Control Group.

Table 2 shows results of the first phase of the study with baseline and three-month nutritional and laboratory parameters for both groups. Analysis of nutritional status over three months in both groups showed a significant difference in the SGA with

\begin{tabular}{|c|c|c|c|c|}
\hline $\begin{array}{l}\text { NUTRITION } \\
\text { IN BOTH GR }\end{array}$ & D LABORATORY PA & ETERS AT BASELINE & AT THE END OF A T & MONTH FOLLOW- \\
\hline \multirow{2}{*}{ Variables } & \multicolumn{2}{|c|}{ Intervention $\mathrm{n}=9$} & \multicolumn{2}{|c|}{ Controls $\mathrm{n}=6$} \\
\hline & Baseline & End & Baseline & End \\
\hline Dry weight (kg) & $60.13 \pm 5.96$ & $61.33 \pm 6.84$ & $55.21 \pm 7.74$ & $56.80 \pm 7.99$ \\
\hline BMI $\left(k g / m^{2}\right)$ & $22.28 \pm 2.32$ & $22.65 \pm 2.51^{*}$ & $20.85 \pm 2.14$ & $21.45 \pm 1.83^{*}$ \\
\hline TS (\%) & $70.60 \pm 30.04$ & $79.26 \pm 29.22^{*}$ & $50.80 \pm 20.01$ & $61.33 \pm 20.55^{*}$ \\
\hline$A C(\%)$ & $90.92 \pm 9.36$ & $94.56 \pm 7.29$ & $78.80 \pm 4.77^{\#}$ & $86.38 \pm 9.84$ \\
\hline AMC (\%) & $94.10 \pm 7.49$ & $96.41 \pm 5.95$ & $83.31 \pm 4.74^{\#}$ & $90.55 \pm 9.20$ \\
\hline Body fat (\%) & $20.85 \pm 8.01$ & $22.16 \pm 7.62$ & $13.14 \pm 6.67$ & $16.91 \pm 5.92$ \\
\hline Fat mass (kg) & $12.76 \pm 5.42$ & $13.76 \pm 5.50^{*}$ & $7.63 \pm 5.34$ & $9.99 \pm 5.00^{*}$ \\
\hline Lean mass $(\mathrm{kg})$ & $47.62 \pm 5.40$ & $47.46 \pm 5.43$ & $47.81 \pm 4.29$ & $46.80 \pm 3.55$ \\
\hline $\mathrm{SGA}^{* *}$ & $15.33 \pm 5.24$ & $12.22 \pm 2.77$ & $16.50 \pm 3.93$ & $16.83 \pm 3.18$ \\
\hline Calcium (mg/dL) & $9.25 \pm 0.85$ & $8.21 \pm 1.61$ & $9.85 \pm 0.62$ & $8.95 \pm 0.78$ \\
\hline Hematocrit (\%) & $33.11 \pm 4.13$ & $35.64 \pm 4.98$ & $31.75 \pm 2.92$ & $34.36 \pm 7.11$ \\
\hline Potassium (mg/dL) & $4.70 \pm 0.44$ & $5.02 \pm 0.59$ & $4.70 \pm 0.31$ & $4.76 \pm 0.64$ \\
\hline Lymphocytes $\left(\mathrm{mm}^{3}\right)$ & $1727.11 \pm 699.48$ & $1713.58 \pm 615.90$ & $1813.08 \pm 661.47$ & $1685.75 \pm 780.65$ \\
\hline Phosphorus (mg/dL) & $4.39 \pm 0.74$ & $4.16 \pm 1.26$ & $4.72 \pm 0.80$ & $5.05 \pm 1.25$ \\
\hline C-reactive protein $(\mathrm{mg} / \mathrm{dL})$ & $3.14(1.16-6.79)$ & $6.02(2.44-14.95)^{*}$ & $2.40(1.08-12.85)$ & $8.6(2.05-37.62)^{*}$ \\
\hline Albumin (g/dL) & $4.32 \pm 0.28$ & $4.13 \pm 0.36$ & $4.26 \pm 0.38$ & $3.88 \pm 0.42$ \\
\hline Pre-BUN (mg/dL) & $143.77 \pm 36.27$ & $144.77 \pm 37.56$ & $118.66 \pm 26.73$ & $119.83 \pm 33.48$ \\
\hline $\mathrm{Kt} / \mathrm{N}$ & $1.52 \pm 0.20$ & $1.73 \pm 0.64$ & $1.54 \pm 0.19$ & $1.84 \pm 0.95$ \\
\hline PCR (g/kg/day) & $1.21 \pm 0.25$ & $1.28 \pm 0.33$ & $1.03 \pm 0.21$ & $1.09 \pm 0.47$ \\
\hline
\end{tabular}

BMI: body mass index; TS: triceps skinfold; AC: arm circumference; AMC: arm muscle circumference; SGA: subjective global assessment; PCRn: protein catabolic rate; ${ }^{*} p<0.05$, comparing to baseline; ${ }^{*} p<0.05$, difference of progression between both groups studied; $\#<<0.05$, comparing to the Intervention Group. 
improvement in the Intervention Group $(p=0.04)$. In the SF-36 (Table 3), RP and BP domains had a significant difference between groups $(p=0.034$ and $p=0.021$, respectively) with improvement in both groups.

Tables 4, 5, and 6 show a comparison of pre- and post- intervention results of 16 subjects who completed the study (second phase). An improvement in the SGA score $(16.18 \pm 4.27$ versus $14.37 \pm 4.20$; $\mathrm{p}=0.040)$ and in the WT $(496.60 \mathrm{~m} \pm 132.59$ versus $547.80 \mathrm{~m} \pm 132.48 ; \mathrm{p}=0.036)$ was observed after three months of dietetic intervention.
The non-industrialized nutritional supplementation was well accepted by all subjects, without side effects or increase in blood glucose in diabetic subjects (glucose $=220 \pm 68.6 \mathrm{mg} / \mathrm{dL}$ pre-intervention versus $194 \pm 89.8 \mathrm{mg} / \mathrm{dL}$ post-intervention, non significant). No gastrointestinal adverse effects were seen. Twelve out of 16 subjects reported that after taking the supplementation they experienced a feeling of well-being and health. Seven out of sixteen reported increased appetite. Fifteen subjects reported that they enjoyed taking the supplementation and that their palatability was very good, even though they did not know the

\section{Table 3 SF-36 QUESTIONNAIRE VARIABLES}

\begin{tabular}{lcccc} 
Variables & \multicolumn{2}{c}{ Intervention $n=9$} & \multicolumn{2}{c}{ Controls $n=6$} \\
\hline Physical role functioning** & $12.5(0.00-43.75)$ & $75.0(6.25-100.0)$ & $25.0(0.0-100.0)$ & $0.00(0.00-75.0)$ \\
Bodily pain** & $52.18 \pm 21.46$ & $64.37 \pm 20.80$ & $71.25 \pm 19.17$ & $53.25 \pm 36.80$ \\
Physical functioning & $55.00 \pm 28.78$ & $56.25 \pm 30.44$ & $70.00 \pm 22.73$ & $55.00 \pm 30.27$ \\
General health & $49.25 \pm 20.33$ & $53.00 \pm 22.66$ & $47.00 \pm 17.79$ & $49.00 \pm 10.45$ \\
Vitality & $55.00 \pm 1647$ & $48.75 \pm 16.85$ & $67.50 \pm 6.45$ & $45.00 \pm 14.71$ \\
Social functioning & $71.87 \pm 30.43$ & $73.43 \pm 32.34$ & $74.37 \pm 43.31$ & $84.37 \pm 11.96$ \\
Role emotional & $0.00(0.00-3.30)$ & $16.65(0.00-66.60)$ & $0.00(0.00-49.95)$ & $16.65(0.00-58.27)$ \\
Mental health & $65.50 \pm 24.55$ & $63.00 \pm 19.91$ & $62.00 \pm 6.92$ & $78.00 \pm 12.00$ \\
\hline
\end{tabular}

** $p<0.05$, difference between groups.

\section{Table 4 COMPARISON OF ALL SUBJECTS PRE- AND POST-INTERVENTION}

\begin{tabular}{lccc} 
Variables & Pre-intervention & Post-intervention & p-value \\
\hline Dry weight $(\mathrm{kg})$ & $64.01 \pm 9.31$ & $63.96 \pm 8.68$ & 0.945 \\
$\mathrm{BMI}\left(\mathrm{kg} / \mathrm{m}^{2}\right)$ & $23.41 \pm 2.94$ & $23.40 \pm 2.60$ & 0.886 \\
TS $(\%)$ & $82.58 \pm 41.32$ & $85.54 \pm 35.12$ & 0.424 \\
AC $(\%)$ & $93.08 \pm 10.10$ & $93.92 \pm 8.91$ & 0.624 \\
AMC (\%) & $95.74 \pm 7.53$ & $95.49 \pm 6.53$ & 0.898 \\
Body fat (\%) & $22.48 \pm 7.37$ & $22.73 \pm 7.78$ & 0.771 \\
Fat mass (kg) & $14.99 \pm 6.75$ & $15.06 \pm 6.62$ & 0.906 \\
Lean mass (kg) & $49.68 \pm 5.77$ & $49.43 \pm 5.25$ & 0.744 \\
Proteins (g/kg/day) & $1.38 \pm 0.77$ & $1.10 \pm 0.66$ & 0.255 \\
Calories (kcal/day) & $28.92 \pm 14.92$ & $24.08 \pm 12.78$ & 0.286 \\
HBV protein (\%) & $59.22 \pm 17.24$ & $55.17 \pm 23.32$ & 0.491 \\
Carbohydrates (\%) & $55.77 \pm 8.63$ & $56.50 \pm 8.25$ & 0.788 \\
Lipids $(\%)$ & $24.27 \pm 6.82$ & $25.55 \pm 5.39$ & 0.417 \\
Phosphorus (mg) & $1,292.50 \pm 693.94$ & $1,006.22 \pm 506.74$ & 0.236 \\
Calcium (mg) & $769.83 \pm 598.42$ & $681.20 \pm 430.28$ & 0.633 \\
Sodium (mg) & $2,270.44 \pm 1,699.68$ & $1,518.88 \pm 1,246.11$ & 0.188 \\
Potassium (mg) & $2,313.46 \pm 1,064.27$ & $1,922.47 \pm 1,024.92$ & 0.288 \\
SGA & $16.18 \pm 4.27$ & $14.37 \pm 4.20$ & 0.040 \\
6-min WT (m) & $496.60 \pm 132.59$ & $547.80 \pm 132.48$ & 0.036 \\
\hline
\end{tabular}

$\mathrm{n}=16$; BMI: body mass index; TS: triceps skinfold; AC: arm circumference; AMC: arm muscle circumference; SGA: subjective global assessment; 6-min WT: six-minute walking test. 


\section{Table 5 COMPARISON OF PRE- AND POST-INTERVENTION LABORATORY TESTS}

\begin{tabular}{lccc} 
Variables & Pre-intervention & Post-intervention & p-value \\
\hline Calcium (mg/dL) & $9.05 \pm 0.94$ & $8.84 \pm 1.10$ & 0.506 \\
Creatinine (mg/dL) & $9.73 \pm 2.39$ & $8.42 \pm 2.59$ & 0.303 \\
Hematocrit (\%) & $34.45 \pm 4.56$ & $36.25 \pm 3.67$ & 0.176 \\
Potassium (mEq/L) & $4.85 \pm 0.44$ & $4.91 \pm 0.51$ & 0.679 \\
Lymphocytes (mm) & $1.806 \pm 687$ & $1.921 \pm 627$ & 0.388 \\
Phosphorus (mg/dL) & $4.63 \pm 0.94$ & $4.72 \pm 1.59$ & 0.803 \\
C-reactive protein (mg/L) & $2.73(1.41-7.63)$ & $6.60(2.18-16.72)$ & 0.163 \\
Albumin (g/dL) & $4.15 \pm 0.35$ & $4.02 \pm 0.38$ & 0.158 \\
Pre-BUN (mg/dL) & $136.50 \pm 31.30$ & $134.56 \pm 31.88$ & 0.757 \\
Kt $/ \mathrm{N}$ & $1.62 \pm 0.60$ & $1.60 \pm 0.51$ & 0.909 \\
PCR (g/kg/day) & $1.18 \pm 0.31$ & $1.17 \pm 0.28$ & 0.918 \\
\hline
\end{tabular}

PCR: protein catabolic rate.

\begin{tabular}{lccc}
\multicolumn{1}{c}{ Table 6} & SF-36 PRE- AND POST-INTERVENTION COMPARISON & & \\
Variables & Pre-intervention & Post-intervention & p-value \\
\hline Physical functioning & $54.54 \pm 28.16$ & $54.54 \pm 30.3$ & 1.00 \\
Physical role functioning & $0.00(0.00-25.00)$ & $25.00(0.00-100.00)$ & 0.066 \\
Bodily pain & $48.13 \pm 21.96$ & $56.46 \pm 24.36$ & 0.153 \\
General health & $50.72 \pm 17.29$ & $46.18 \pm 22.85$ & 0.440 \\
Vitality & $55.00 \pm 14.31$ & $50.45 \pm 14.90$ & 0.211 \\
Social functioning & $75.00 \pm 26.22$ & $77.27 \pm 29.48$ & 0.617 \\
Emotional role & $0.00(0.00-33.30)$ & $0.00(0.00-66.60)$ & 0.157 \\
Mental health & $68.00 \pm 21.31$ & $66.18 \pm 20.10$ & 0.700
\end{tabular}

ingredients of the recipe. The subjects had great expectations about the food's content. Thirteen subjects expected to receive the supplementation and said that the received amount was small. At the study's completion, 11 out of 16 subjects expressed a desire to continue receiving the supplementation.

\section{Discussion}

There is evidence that the nutritional status assessment aimed at identifying $\mathrm{MN}$ or individuals at risk is independently associated with morbidity and mortality in CKD patients, especially in those on HD. ${ }^{9,16-18}$

Studies on the nutritional status of dialysis patients reported 6 to $8 \%$ of severe malnutrition and about $33 \%$ of mild-to-moderate malnutrition. ${ }^{19-23}$ In our study, $27 \%$ of subjects were at nutritional risk, including severe and mild-to-moderate malnutrition.

Cappeli et al., ${ }^{24}$ in a non-randomized study with a large sample of $\mathrm{MN}$ patients on $\mathrm{HD}$, suggested that
IDPN intervention can be associated with reduced rates of hospital admission and mortality.

Nutritional intervention in MN patients on HD is often complicated and costly. Prospective randomized studies have not consistently shown evidence of its benefit although intuitively it is expected to be beneficial. ${ }^{25}$ In fact, some authors have pointed out that oral supplementation administered during $\mathrm{HD}$ can provide nutritional benefits to $\mathrm{MN}$ patients. ${ }^{5,6,26,27}$

In our study there was an improvement in the SGA score of patients who received the intervention when compared to those who did not receive it. Czekalski ${ }^{28}$ reported similar findings in the study with parenteral amino acid supplementation. After sixth months, these authors verified a five-point reduction in the SGA scale. While studying oral supplementation, Caglar et al. ${ }^{6}$ found a $14 \%$ decrease in SGA after the intervention compared to baseline. Although they studied a larger sample, there was no Control Group. 
Improved quality of life was also seen in our patients, who received the intervention compared to those who did not receive it, especially in the RP and BP domains. Shah et al. only reported significant improvement in the physical domain of the patients' quality of life. ${ }^{29}$ There are few well-designed studies on the effect of either oral or IDPN nutritional therapy on patients' quality of life. ${ }^{30}$ Eustace et al. ${ }^{31}$ did not find any significant differences in the SF-12 physical health domain between those who received essential amino acid supplementation and the Placebo Group.

In the six-min. WT, subjects were able to walk larger distances after the intervention. There are no other studies of the effect of nutritional supplementation on the WT.

Nutritional supplementation was well accepted by our patients. They reported increased appetite, a finding corroborated by Foulks ${ }^{32}$ who also found gains of lean body mass and increased levels of serum albumin after therapy. More recently, Veeneman et al..$^{5}$ evaluated the effect of providing a meal during HD on total body protein balance. The meal was offered as a protein and energy - enriched yogurt, cream and powdered milk, and study results showed that such intervention during HD produced a positive protein balance compared to an off-dialysis day. However, it has not yet been established whether this seemingly short-term oral supplementation can offer benefits or improve the overall nutritional status of MN patients on HD in the long-term. As for the good acceptance of the supplementation in our study, the same was not found by Caglar et al., ${ }^{6}$ who reported that 27 of 85 patients who were offered an industrialized nutritional supplementation refused it.

Eustace et al. ${ }^{31}$ investigated the beneficial effects of oral amino acid supplementation in patients on $\mathrm{HD}$ and $\mathrm{PD}$ in a placebo-controlled randomized prospective study. As in our study, they did not find significant differences in anthropometric measures, food intake (calories and proteins), $\mathrm{Kt} / \mathrm{V}$, albumin, creatinine, phosphorus and hematocrit, but this could be explained by either the short time of supplementation or the inadequate "dose" of the intervention.

Dietitian care and intensive monitoring may explain the nonspecific improvement effects seen in our study. A similar finding was reported in another study, ${ }^{33}$ in which the authors demonstrated that IDPN was an effective therapeutic approach in patients with hypoalbuminemia or in those with inadequate protein intake. Nevertheless, these improvements may have resulted from the dedication and care provided by nutritionists and health providers or even from patient's self-motivation.

The non-industrialized supplementation provided in our study proved to be affordable in a developing country, such as Brazil. The monthly cost per patient was on average US\$2.00. A year of therapy per patient would amount US\$24.00, much less than what is required for industrialized supplementation therapy. Chertow et al. ${ }^{34}$ based on an estimated cost to treat 17 patients, found that the yearly cost for IDPN therapy per patient would be around US\$ 510 . Comparatively, a year of improvement in the quality of life associated with the erythropoietin therapy amounts to at least US\$130,000.

In conclusion, overall nutritional intervention produced positive nonspecific and specific effects in all patients studied. Customized nutritional supplementation proved to be palatable, practical, and a low cost treatment. Its clinical impact and effectiveness should be further assessed in a larger group of patients for a longer period.

\section{References}

1. Ikizler TA. Protein and energy: Recommended intake and nutrient supplementation in chronic dialysis patients. Semin Dial 2004;17:471-8.

2. National Kidney Foundation K/DOQI clinical practice guidelines for nutrition in chronic reanl failure. Am J Kidney Dis 2000;35(Suppl):S1-140.

3. Stenvinkel P, Heimbürger O, Lindholm B, Bergstrom J, Kaysen GA. Are there two types of malnutrition in chronic renal failure? Evidence for relationships between malnutrition, inflammation and atherosclerosis (MIA syndrome). Nephrol Dial Transplant 2000;15:953-60.

4. Pupim LB, Majchrzak KM, Flakoll PJ, Ikizler TA. Intradialytic oral nutrition improves protein homeostasis in chronic hemodialysis patients with deranged nutritional status. J Am Soc Nephrol 2006;17:3149-57.

5. Veeneman JM, Kingma HA, Boer TS, Stellaard F, De Jong PE, Reijngoud DJ, et al. Protein intake during hemodialysis maintains a positive whole body protein balance in chronic hemodialysis patients. Am J Phisiol Endocrinol Metab 2003;284:954-65.

6. Caglar K, Fedje L, Dimmitt R, Hakim RM, Shyr Y, Ikizler TA. Therapeutic effects of oral nutritional supplementation during hemodialysis. Kidney Int 2002;62:1054-9.

7. Jeejeebhoy KN, Detsky AS, Baker JP. Assessment of nutritional status. J Parenter Enteral Nutr 1990;14:S193-6.

8. Jones CH, Wells LM, Wolfenden RC. Is subjective global assessment a reliable measure of nutritional status in hemodialysis? J Renal Nutr 2004;14:26-30.

9. Riella MC, Martins C. Nutrição e o Rim. Rio de Janeiro: Guanabara Koogan; 2001.

10. Kopple J, Massry SG. Cuidados nutricionais das doenças renais. Rio de Janeiro: Guanabara Koogan; 2006. 
11. Kalantar-Zadeh K, Kleiner M, Dunne E, Lee GH, Luft FC. A modified quantitative subjective global assessment of nutrition for dialysis patients. Nephrol Dial Transplant 1999;14:1732-8.

12. Daugirdas JT. Second generation logarithmic estimates of single pool variable volume $\mathrm{Kt} / \mathrm{V}$ : an analysis or error. J Am Soc Nephrol 1993;4:1205-13.

13. Oliveira Jr. MT, Guimarães GV, Barretto ACP. Teste de 6 minutos em Insuficiência Cardíaca. Arq Bras Cardiol 1996;67:373-4

14. Guyatt GH, Sullivan MJ, Fallen EL, Taylor DW, Pugsley SO, Berman LB. The 6-minute walk: a new measure of exercise capacity in patients with chronic heart failure. Can Med Assoc J 1985;132:919-22.

15. Ciconelli RM. Tradução para o português e validação do questionário genérico de avaliação de qualidade de vida "Medical Outcomes Study 36 - Item Short-Form Health Survey (SF-36)". [dissertação]. São Paulo: Universidade Federal de São Paulo; 1997.

16. Williams AJ, McArley A. Body composition, treatment time, and outcome in hemodialysis patients. J Renal Nutr 1999;9:157-62.

17. Kopple J. Nutritional status as a predictor of morbity and mortality in maintenace dilysis patients. Asaio J 1997;43:246-50.

18. Leavey SF, Strawderman RL, Jones CA, Port FK, Held PJ. Simple nutritional indicators as independent predictors of mortality in hemodialysis patients. Am J Kidney Dis 1998;31:997-1006.

19. Cianciaruso B, Kopple JD, Brunori G, Traverso G, Panarello G, Strippoli P, et al. Cross-sectional comparison of malnutrition in continuous ambulatory peritoneal dialysis and hemodialysis patients. Am J Kidney Dis 1995;26:475-86.

20. França FB, Lugon JR. Revisão/Atualização em diálise: nutrição em hemodiálise. J Bras Nefrol 1998;20:484-95.

21. Bilbrey C, Cohen T. Identification and treatment of protein calorie malnutrition in chronic hemodialysis patients. Nephrol Dial Transplant 1989;18:669-78.

22. Markmann P. Nutritional status of patients of hemodialysis and peritoneal dialysis. Clin Nephrol 1988;29:75-8.
23. Aparício M, Cano N, Chauveau P, Azar R, Canaud B, Flory A, et al. Nutritional status of hemodialysis patients: a French national cooperative study. Nephrol Dial Transplant 1999;14:1679-86.

24. Cappeli J, Kushner H, Camiscioli TC, Chen SM, Torres MA. Effect of intradialytic parenteral nutrition on mortality rates in end-stage renal disease care. Am J Kidney Dis 1994;23:808-16.

25. Foulks C, Goldestein D, MP K, et al. Indications for the use of intradialytic parenteral nutrition in the malnourished hemodialysis patients. J Renal Nutr 1991;1:23-33.

26. Cuppari L, et al. Effectiveness of oral energy-protein supplementation in severely malnourished hemodialysis patients. J Renal Nutr 1994;4:127-35.

27. Wilson B, Fernandez-Madrid A, Hayes A, Hermann K, Smith J, Wassell A. Comparison of the effects of two early intervention strategies on the health outcome of malnourished hemodialysis patients. J Renal Nutr 2001;11:1667-71.

28. Czekalski SRH. Intradialytic amino acids supplementation in hemodialysis patients with malnutrition: results of a multicenter cohort study. J Renal Nutr 2004;14:82-8.

29. Shah NA, Mueller BA, Thomas J, Kraus MA, MK S. Effects of supplemental enteral nutrition on nutritional status and quality of life in ESRD patients receiving hemodialysis. J Am Soc Nephrol 1999;10:303A.

30. United States Renal Data System. Patient mortality and survival. Am J Kidney Dis 1997;30 (Suppl):S86-106.

31. Eustace J, Coresh J, Walser M. Randomized double-blind trial of oral essential amino acids for dialysis-associated hypoalbuminemia. Kidney Int 2000;57:2527-38.

32. Foulks C. The effect of intradialytic parenteral nutrition on hospitalization rate and mortality in malnourished hemodialysis patients. J Renal Nutr 1991;4:5-10.

33. Moore L, Acchiardo S. Aggressive nutritional supplementation in chronic hemodialysis patients. CRN Q 1987;11:14-7.

34. Chertow G, Ling J, Lew NL, Lazarus JM, Lowrie EG. The association of intradialytic parenteral nutrition administration with survival in hemodialysis patients. Am J Kidney Dis 1994;24:912-20. 